\title{
ALTERNATIVE STRATEGY TO THE CRISIS IN THE CENTRAL AFRICAN REPUBLIC: THE ESTABLISHMENT OF A PERMANENT AFRICAN PEACEKEEPING FORCE
}

\author{
Josias Marcos de Resende Silva ${ }^{1}$
}

\section{Introduction}

Since its independence from France in I960, Central African Republic (CAR) has been seen as a failed state. A series of coups and counter-coups have severely affected the politics and the fragile economy of the country in the last six decades. In 2013, the crisis in Central African Republic has significantly worsened after a coup led by Muslim majority rebel group, called Séléka, who are the minority. Christian militias, also known as anti-Balaka, retaliated. The dispute over territory and power between the two groups contributed to the humanitarian chaos found today in CAR. According to Arieff $(20 \mathrm{I} 4,28)$, in mid-January $20 \mathrm{I} 4$, about 900,000 people (nearly one in five) had been internally displaced, while another 86,000 had fled to neighboring countries as refugees. In addition to that, United Nations (UN) agencies estimate that 2.6 million people, or half of the population, need humanitarian aid and that $60 \%$ of families do not have food stocks available.

As a result of intense international pressure, President Michel Djotodia, leader of the Séléka, decided to resign in January 20I4. The Christian Catherine Samba-Panza, a businesswoman and former mayor of the capital Bangui, was chosen as interim president to head a transitional government in the country. Due to the catastrophic situation in CAR, the Security Council authorized on April IO 20I4 the deployment of a United Nations multidimensional peacekeeping operation, MINUSCA $^{2}$, replacing the

\footnotetext{
I American Military University, Charles Town, USA. E-mail: dojosias@gmail.com 2 French acronym, Mission Multidimensionnelle Intégrée des Nations Unies pour la Stabilisation en République Centrafricaine.
} 
temporary mission led by the African Union (MISCA 3 ) and backed by French troops. The highest priority of MINUSCA is the protection of civilians. Its other tasks include support the transition process; facilitating humanitarian assistance; promotion and protection of human rights; support for justice and the rule of law; and disarmament, demobilization, reintegration and repatriation processes (UN 20I8).

According to United Nations (2018), one of the major goals of MINUSCA, during the early phase of its deployment, was to provide a secure environment, essential for progress in other areas. In this deteriorated and hostile place, MINUSCA needs to try innovative strategies to contain the conflict at first. Thus, aiming to include non-Western ideas in a conflict resolution process and take advantage of regional cultural similarities, will the establishment of a permanent African peacekeeping force, as a branch of African Union and under control of MINUSCA, increase the chance of success of the multidimensional peacekeeping operation in the Central African Republic?

The purpose of this essay is to examine a new concept for structuring peacekeeping forces in Africa, particularly in Central African Republic. Traditional strategies have been used in peacekeeping operations in the continent, many of them without success. Central African Republic is immersed in a serious humanitarian crisis, which has worsened in recent years. Violent militia groups, some supported by neighboring states governments, have attacked each other and civilian population, in an attempt to control territory and increase their power. Based on the context of CAR, this paper will analyze if a permanent African peacekeeping force, as an African Union branch, would be better trained, better paid, and more impartial than the multinational contingents deployed today in Africa.

\section{The conflict in the Central African Republic}

Arieff examines the background on the evolving political, security, and humanitarian crisis in CAR. He stresses that religion is not the primary cause of the conflict, and local religious leaders have been working for peace and reconciliation during the crisis. The roots of the conflict are the intercommunal disputes over access to resources, control over trade, and national identity. Also, competition for land has fueled frictions between herders, who are mostly Muslims, and farmers, most of whom are Christians or

3 French acronym, Mission Internationale de Soutien à la Centrafrique sous Conduite Africaine. 
followers of indigenous religions (Arieff 20I4, 35). According to Arieff, some external players deserve special attention. The Economic Community of Central African States (ECCAS) has attempted to play a prominent role in CAR by mediating peace agreements, deploying peacekeeping troops, and influencing the selection of the CAR's political leadership. However, regional rivalries and lack of expertise have undermined the ECCAS' efforts (Arieff 20I4, 37). Another relevant player is Chad's president, Idriss Déby. He supported former president Bozizé to reach power in CAR. Nevertheless, when he became dissatisfied with Bozizé, he allowed Séléka to seize power and overthrow the president. Arieff affirms that the influence of Chad's president in CAR politics has constantly contributed to tension between Muslims and Christians. Finally, South Africa started to cultivate growing ties with Bozizé's government in 20I2. South Africa's intention was to increase its influence in Francophone Africa, which challenged French and Chadian interests (Arieff 2012, 38).

Among the internal players, Arieff analyzes the conflict from an ethnic perspective, with special attention to the role of Séléka (currently ex-Séléka) and anti-Balaka groups. He stresses that there has been a de facto foreign occupation of CAR since many Séléka combatants come from Chad and Sudan. However, this information is difficult to assess given the inconsistent distribution of identity papers among the general population. Also, the term foreigner is often used by Southerners and non-Muslims to refer to Northeastern ethnic groups with cross-border family ties (Arieff 20I4, 33). Thus, although there is a relevant presence of foreigners in the conflict, especially within the Séléka group, the exact number of non-nationals is impossible to define. On the other hand, anti-Balaka groups seem to be integrated by former military officers. Arieff affirms that the former president Bozizé (an evangelical Christian) must be supporting them from his exile, due to the sophisticated military capacities of the anti-Balaka groups (Arieff 20I4, 34).

Sibbald (20I4) agrees with Arieff regarding the non-religious origin of the CAR's conflict. She analyzes the conflict from a humanitarian perspective and reports the work of Doctors Without Borders (MSF) in the country. Sibbald affirms that "the Muslim people's grievances are political and economic, not religious, but fighting has increasingly taken a sectarian tone since a coup in March 2013" (Sibbald 2014, 336). She explains that about $80 \%$ of the CAR's population is Christian. The Muslim population is concentrated in the marginalized north border near Sudan and Chad. She also stresses the terrible sanitary conditions of the capital Bangui, in which I00.000 Christians (about $25 \%$ of the local population) were living at the M'poko airport with less than four liters of water per person per day. 
While the focus of the international community has been the capital Bangui, International Crisis Group (ICG) draws attention to the clashes in the rural areas, which are creating a "conflict within the conflict". The struggle between ex-Séléka and anti-Balaka militiamen has led to a frequent struggle between pastoralist and farming communities since 20I3. ICG describes in detail the formation of various inter-communal groups and the roots of the conflict since CAR's independence. According to ICG $(2015,4)$, cattle is an important economic capital and has long been both a source of wealth and a cause of violence. The exploitation of pastoralists by CAR's army for the last twenty years has contributed to their impoverishment and further militarization. During this period, their herds have drastically decreased as a result of insecurity, inflation and an increase in family size. Since the war started, many pastoralists have been forced to take refuge in other countries or in other CAR regions, causing the collapse of the livestock farming sector and the radicalization of some pastoralist groups. ICG stresses that the relationship between ex-Séleka groups and pastoralists changes according to the region and sociology. While some pastoralists are subjected to extortion by ex-Séléka, Arab pastoralists who came from Chad in the I980s have a good relationship with ex-Séléka combatants (ICG 20I5, 6). ICG also explains exSéléka and anti-Balaka different strategies to control territory. The anti-Balaka groups often try to control sections of roads so they can levy informal taxes and steal goods. On the other hand, ex-Séléka groups take over the entire administration of towns and even arbitrate disputes between farmers and pastoralists. This appropriation of traditional functions by ex-Séléka warlords has led to the breakdown of the traditional practice of seeking informal agreements and traditional amicable settlements that maintained a certain social cohesion in northern parts of the country. The participation of these militiamen in this process has undermined the strategy of NGOs to revitalize the traditional mediation committees and restore social ties between farmers and pastoralists (ICG 2015, 7).

International Institute for Strategic Studies (IISS) also examines the background of the conflict in CAR and some of its major players, particularly France. The IISS explains that wracked by coup and counter-coup, Central African Republic has been ruled mostly by military leaders since its independence from France in I960. Due to the country's political turmoil and unstable security, its economy has never improved. The humanitarian situation and violence have significantly worsened since the last coup in 20I3, which made UN and AU implement the MINUSCA in 2014. 


\section{The United Nations presence in the Central African Republic}

Peacekeeping operations have proven to be essential to conflict reduction around the world. Based on a statistical study, Hegre, Hultman, and Nygard affirm that peacekeeping operations with a high annual budget (US $\$ 500$ million or more) decrease the risk of major conflicts in $80 \%$. High annual budget operations include MINUSCA, which had a budget of US\$ 882 million for the year 20I7-I8. They also assert that East, Central, and Southern Africa are some of the regions where peacekeeping operations have the strongest effect. In these African regions, strong mandates such as MINUSCA's reduce the predicted incidence of major conflict from about $8 \%$ of the countries to about $3 \%$, corresponding to more than two conflicts every year to less than one (Hegre, Hultman, and Nygard 2013, 24).

According to United Nations (20I8), MINUSCA is one of the largest peacekeeping operations in the world. MINUSCA was implemented under Chapter VII of the United Nations Charter, which means that Security Council authorizes MINUSCA to take all necessary means to carry out its mandate, within its capabilities and its areas of deployment. It is comprised of $\mathrm{I} 2,870$ military personnel, including 480 military observers and 276 staff officers, as well as 2,080 police personnel, including 1572 formed police unit personnel, 400 individual police officers, and to 8 corrections officers. African and Asian countries such as Rwanda, Egypt, Cameroon, Senegal, Pakistan, and Bangladesh are the main troop or police contributors in MINUSCA, which can be considered one of the most dangerous ongoing UN peacekeeping operations totaling 75 peacekeeping deaths.

Although statistics show that peace operations with a strong mandate significantly affect the risk of major conflicts in the Central African region, MINUSCA is far from being effective. Barbosa, who was a Military Observer (MILOBS) in CAR between 2014-I5, claims that most of the troops contributing countries in MINUSCA have national interests in the region. Cameroon and Democratic Republic of the Congo (DRC) have permeable borders with CAR and have nomadic populations entering CAR's territory. The operation SANGARIS, which was conducted by France within CAR, had its own mandate and only defended French interests in the region. Moreover, Chadian troops were withdrawn from CAR because they clearly took sides in the conflict, affecting MINUSCA's impartiality and credibility. Other factors that contribute to MINUSCA's ineffectiveness are the lack of action at the political level, the fractionalization of the rebel groups, the insufficient 
number of UN troops, the low level of troop training, and the refusal of some troops to take risks. Barbosa also stresses the poor conditions of the African troops in CAR, who do not receive their salaries every month, even though UN pays African countries properly (Barbosa 20I5).

Even more serious are the consequences of the lack of professionalism and integrity of African troops that are part of MINUSCA. According to United Nations Security Council (20I4), Burundian, Chadian, Congolese and Gabonese MISCA/MINUSCA soldiers were responsible for 2I violations of human rights from December 20I3 to August 20I4 such as torture, murder, and even the killing of a group of Christians. On the other hand, in this same period, the number of civilian deaths declined from I2I2 to 7 per month (Panel of Experts 20I4), which proves that the peacekeeping operation in CAR is highly necessary.

\section{The employment of regional peacekeeping forces}

The neo-colonization, which divided Africa into colonies without considering the existing ethnic groups, contributed to the containment of different peoples, cultures, and religions within the same state. A large number of conflicts have broken out within African states as a result of the disputes between these ethnic groups for basic resources, in a continent plagued by poverty. In CAR, inter-communal disputes that exist since the country's independence evolved into a bloody conflict between armed militias. After several attempts to resolve the conflict by the international community, traditional peacekeeping strategies have been ineffective. In this complex and violent environment of CAR, in which UN troops have not been able to completely fulfill their mission, the employment of a permanent African peacekeeping force appears as an alternative.

A theory that is helpful and provides a theoretical support for the designation of regional intervention forces is: "The Clash of Civilizations?" by Samuel Huntington. According to Huntington (I993, 24), a civilization is "the highest cultural grouping of people and the broadest level of cultural identity people have short of that which distinguishes humans from other species." Moreover, he explains that different civilizations have different views on religion, the role of the state, citizens, women, children, marriage, rights, authority, etc. Based on these parameters, Huntington divides the world into eight major civilizations: Western, Confucian, Japanese, Islamic, Hindu, Slavic-Orthodox, Latin American and possibly African civilization 
(Huntington I993, 25). He also affirms that major conflicts are likely to happen between two different civilizations and regionalism may succeed only within the same civilization. For that reason, according to Huntington's theory, regional intervention forces would be likely to succeed in peace enforcement operations rather than non-regional intervention forces.

In March 2000 , a series of factors including the United Nations' major failings in the I990s, the renewed demand for peace operations, and the near collapse of the UN mission in Sierra Leone led the UN SecretaryGeneral to set up a Panel on the United Nations Peace Operations, chaired by the former Algerian foreign minister Lakhdar Brahimi (Bellamy, Williams and Griffin 20I0, I29). In September 2000, as a result of the panel, the Brahimi Report made several recommendations to promote better management of peace operations. Among the recommendations, the report stressed that the military component of a peace operation should be robust enough to defend itself effectively and protect civilians under its care. A few years later, as an outcome of the 2005 World Summit, member states endorsed the responsibility to protect $(\mathrm{R} 2 \mathrm{P})$ principle, which states that the international community must intervene when host states are unable to avoid violent human rights abuses.

Moreover, motivated mainly by its inability to prevent genocide in Rwanda and Srebrenica (Bosnia) in the mid-I990s, UN realized that it should be prepared to engage in more robust or muscular peacekeeping (Ucko and Berdal 20I5, 7). For that reason, lately, the UN has issued mandates under Chapter VII of the UN Charter, allowing the use of all necessary means with the main objective to protect civilians, including a military intervention force in some cases (Bellamy 20I4, 55).

Therefore, in the last two decades peace operations have undergone significant changes. While traditional peacekeeping operations often took place in an interstate conflict context, the most recent operations have been implemented to resolve conflicts in a civil war environment. This new concept of peacekeeping operation, also called multidimensional or complex, in addition to the military and police components, includes activities related to human rights, protection of civilians, refugees, demobilization and reintegration of combatants, and development (Aguilar 2015, 254). Unlike the traditional UN missions, Aguilar states that current peace operations have security only as part of the peace process. He points out, as the main factors for this change, the frequent occurrence of civil wars, in which the principle of consensus does not apply to the states involved, but to all parties to the conflict (Aguilar 2015, 255). In this type of conflict, which usually occurs in failed states, the civilian population is the biggest victim. 
In this scenario, Aguilar advocates the use of regional intervention forces rather than non-regional intervention forces in peace operations, especially the ones under the Chapter VII of the UN Charter such as MINUSCA. The author states that the factors that contribute to this new trend are the search for greater regional participation, reduction of costs, and the growing importance of regional organizations. He also notes that of the 50 peace operations in 20II, regional organizations and institutions were responsible for 20 (Aguilar 20I5, 264). Another important trend, according to Aguilar, is the higher number of peace operations carried out by the South. The relevant amount of peace operations in Africa helps to explain this phenomenon and the strong engagement of African Union in the continent (Aguilar 20I5). In Congo, the recently created Force Intervention Brigade (FIB) made up of regional troops, has been victorious in several military clashes, helping the national army to retake part of the Congolese territory and fight the M23 and all other armed groups that violate human rights (Aguilar 2015, 264).

Concerning the situation in the DRC, Doss explains that in late 20I2, a rebel force captured the capital of North Kivu province in the eastern Congo, the city of Goma. Incredibly, this event took place in a state where there was the presence of the largest peacekeeping force ever deployed in a conflict zone. For that reason, Doss affirms that the fall of Goma made UN wonder about the methods of conflict resolution employed in peace operations (Doss 20I4, 703). The UN then decided that the operation in the Congo, MONUC4, would be renamed MONUSCO${ }^{5}$, to characterize a new phase of the mission. Some tragic events prompted the UN's change of behavior. Among them, Doss affirms that one of the most serious problems faced by MONUC, in 2010, was the horrendous mass rape in North Kivu. The slow response of MONUC resulted in severe criticism from the international community toward the UN operation. Worse than the mass rape, Doss asserts that the mutiny led by the rebel group M23 in 2012 caused a stir around the world. He explains that the actions of the M23 quickly overwhelmed the Congolese national army, which culminated in the fall of Goma (Doss 2014, 726). As a new strategy, the Security Council authorized, on an exceptional basis and without any prejudice of the agreed principles of peacekeeping, the deployment of a regional intervention brigade, also known as Force Intervention Brigade (FIB). The brigade is entrusted with an offensive mandate and tasked to

4 French acronym, Mission de l'Organisation des Nations Unies en République Démocratique du Congo.

5 French acronym, Mission de l'Organisation des Nations Unies pour la Stabilisation en République Démocratique du Congo. 
neutralize armed groups. It consists of three infantry battalions, one artillery, and one Special Forces and Reconnaissance Company. An important detail is that the brigade is composed only of troops from African nations, operating under the direct order of the Force Commander.

Substantial victories of the FIB, which managed to dislodge the notorious M23 from towns such as Kibumba, Rumangabo and Rutshuru within only four days (25-28 October 2013), brought a sense of triumph and confidence to many as nobody had predicted such a quick defeat of the rebels. In a very short time, there was already overwhelming evidence that the existential threats in the region had been drastically reduced (Namangale 20I4, 8I), proving the benefits of a regional force in the context of a peacekeeping operation.

Arredondo agrees with Aguilar on the tendency toward regionalism in peace operations, expressing the Latin American standpoint. According to him, Latin America shows strong support for the principle of nonintervention in the internal affairs and a clear reluctance to support any kind of foreign intervention, especially from Western states. Arredondo explains that this reluctance is due to historical reasons, mainly as a consequence of the American interventions throughout the $20^{\text {th }}$ Century (Arredondo 20I4, 277). For that reason, he approves the strategy used in the UN mission in Haiti $\left(\right.$ MINUSTAH $^{6}$ ), which was mainly composed of a regional peacekeeping force, under the leadership of another Latin American nation, Brazil. MINUSTAH successfully ended its military operations in Haiti in 20I7, after approximately I3 years in the Caribbean country. On the other hand, Arredondo criticizes the participation of Western nations, through NATO, in Libya. He explains that the Resolution I973 had the support of the Arab League and the African Union, which gave it an unquestionable legitimacy at first. The resolution established a no-fly zone and naval embargo on Libya, and authorized the intervention force to take all necessary measures to protect civilians, but expressly excluded the foreign occupation of any part of Libyan territory. Arredondo emphasizes that these conditions 'were raped' by NATO, transforming the mandate into a regime change operation and undermining the principle of $\mathrm{R}_{2} \mathrm{P}$ (Arredondo 20I4, 285).

Diehl (I994, I22) defends the use of regional peacekeeping forces arguing that they have the advantages of achieving greater consensus within member states, broader support from the disputants, more control over thirdparty states, and heightened chances for conflict resolution. That happens because states in the same region usually have the same development

6 French acronym, Mission des Nations Unies pour la Stabilisation en Haïti. 
level, similar political systems, and share historical, ethnic, or tribal roots. However, a series of factors prevent African troops from being effective. Thus, peacekeeping forces in Africa need structural changes to improve their capacity, professionalism, and effectiveness. The author also advocates the employment of a permanent UN peacekeeping force, asserting that these units would receive better training, deploy faster in a conflict zone, have more experience in peace operations, and avoid the unwillingness of some countries to support a particular UN mission (Diehl I994, I65). Diehl considers both the use of regional forces and the existence of a permanent UN peacekeeping force as alternative strategies for peace operations.

Barbosa argues that in a scenario in which a permanent African peacekeeping force was paid, equipped, adequately supervised and trained with the support of the international community, there would probably be an increase in its efficiency. This permanent African peacekeeping force would allow a faster deployment in the events of serious violations, reduce logistical problems, and provide a long-term mindset change and training for the troops (Barbosa 20I5). Nevertheless, in the case of an intrastate conflict, it is desirable that states which contribute to the regional intervention force do not share borders with the disputants. Also, the historical relationship between states in a regional organization needs to be observed. For example, a regional force led by the US within the framework of OAS may serve the US interests and will have less legitimacy than a UN force in Latin America (Diehl I994, I22).

Thus, the existing literature addresses the roots and the escalation of the conflict in the CAR. The authors agree that a dispute over basic resources took a sectarian tone and turned into a serious ethnic conflict involving violent militias in a failed state. Even after the implementation of the AU-led MISCA, followed by the establishment of the UN-led MINUSCA, the conflict has not stopped. Regional peacekeeping forces have emerged as a valid option in complex UN peace operations, proving to be effective tools to contain conflict and stabilize troubled regions. However, regional troops currently deployed in CAR lack better payment, training, and motivation, mostly because their countries make bad use of the resources from the UN. Hence, in order to contain the ongoing conflict in CAR, the creation and the deployment of a permanent African peacekeeping force, as a branch of $\mathrm{AU}$, emerges as an alternative strategy. 


\section{Conclusions}

After examining academic research and an interview with the Brazilian MILOBS in Central African Republic, it is possible to verify that the establishment of a permanent African peacekeeping force, as a branch of African Union and under the control of MINUSCA, increases the chance of success of the multidimensional peacekeeping operation in Central African Republic. The current military organization of MINUSCA, involving national contingents from several countries, mostly African, faces serious structural problems and contributes to the ineffectiveness of the UN mission in CAR.

The combination of Diehl's alternative strategies (the establishment of a permanent UN peacekeeping force and peace operations conducted by regional organizations) offered a solid argument for the containment of the conflict in Central African Republic, which is the establishment of a permanent African peacekeeping force. It provided explanations for understanding the benefits of a permanent UN peacekeeping force, only focused on peace operations. It also described the advantages of the employment of regional forces in conflicts and the reasons why these forces are more likely to succeed in peace operations.

As a result, it is possible to conclude that African troops in MINUSCA are not effective to contain the conflict in CAR. Obstacles such as low level of training, refusal to take risks, poor conditions, partiality, and violation of human rights prevent the current African contingent to achieve the high standard necessary for the success of MINUSCA. Most of these problems are direct consequences of bad economic and social conditions associated with poor national policies in the troop contributing countries. Considering this context, a permanent African peacekeeping force, as a branch of African Union and under the control of MINUSCA, becomes a viable proposal in CAR. An African multinational troop would be better paid and equipped because the resources would not pass through national governments. Also, troops would be more impartial because they would not represent their countries, but only AU. Finally, the level of training would be improved since this permanent African troop would be especially prepared and shaped for peacekeeping missions. Therefore, there is evidence that a permanent African peacekeeping force is the most appropriate troop to support the peace efforts in CAR.

This study does not exhaust the knowledge on alternative strategies for the effectiveness of MINUSCA, the establishment of a permanent UN 
peacekeeping force, and peace operations conducted by regional organizations. The UN has never had its own permanent military force, as well as the AU. Thus, more studies concerning the viability of such military force, its structure, employment, and acceptability by national states would efficiently complement this paper.

\section{REFERENCES}

Aguilar, Sérgio Luiz Cruz. 20I5. "Operações de Paz: novos mandatos e suas implicações para os países contribuintes com tropas. (Portuguese)." História e Cultura 4, no. I: 254-276. Directory of Open Access Journals.

Arieff, Alexis. 20I4. "Crisis in the Central African Republic." Current Politics and Economics of Africa 7, no. I: 27-46. http://search.proquest.com/ docview/ i622616796? accountid=8289.

Arredondo, Ricardo. 20I4. "La Responsabilidad de Proteger: la Perspectiva Latinoamericana. (Spanish).” Araucariai6, no. 32. Directory of Open Access Journals.

Barbosa, K. 20I5. Interviewed by Silva, Josias. Rio de Janeiro. August I8.

Bellamy, Alex J., Paul D. Williams and Stuart Griffin. 2010. Understanding Peacekeeping. 2nd ed. Cambridge: Polity Press.

Diehl, Paul F. I994. International Peacekeeping. Baltimore and London: The Johns Hopkins University Press.

Doss, Alan. 20I4. "In the Footsteps of Dr. Bunche: The Congo, UN Peacekeeping, and the Use of Force." Journal of Strategic Studies 37, no. 5. http://www.tand fonline.com.ezproxyI.apus.edu/doi/abs/ıo.1080/ OI402390.2014.908284\#VTbTtebF-So.

Hegre, Havard, Lisa Hultman, and Havard Nygard. 2013. "Evaluating the conflict-reducing effect of UN peacekeeping operations." Centre for the Study of Civil War. https://havardhegre.files.wordpress. com/20I3/10/pko_prediction_2012.pdf

Huntington, Samuel P. I993. “The Clash of Civilizations?” Foreign Affairs 72, no. 3: 22-49. Accessed April 23, 2015. Proquest Military Collection.

International Crisis Group. 20I5. "The Central African Republic's Hidden Conflict." http://www.crisisgroup.org/ /media/Files/africa/ 
central-africa/central-african-republic/bio5-la-face-cachee-du-conflit-centrafricain-english.pdf

Namangale, Clement. 20I4. "Dynamics of Conflict Management in the Democratic Republic of the Congo." PRISM Security Studies Journal 5, no. 2: 73-83. International Security \& Counter Terrorism Reference Center, EBSCOhost.

Sibbald, Barbara. 20I4. "Address extreme violence in Central African Republic now: MSF." Canadian Medical Association Journal I86, no. 5: 335-336. http://search.proquest.com/docview/1522776083?accountid $=8289$.

The International Institute for Strategic Studies. 20I3. "Central African Republic: Instability and Intervention." Strategic Comments I9, no. 9. http://www.tandfonline.com.ezproxy2.apus.edu/doi/pdf/ı0.1080/ I3567888.2013.877693

Ucko, David, and Mats Berdal. 20I5. "The Use of Force in Peacekeeping Operations." The Rusi Journal I6o, no. I. http://www.tandfonline. com.ezproxy2.apus.edu/doi/abs/10.1080/03071847.2015.1016718 \#.VTbJU-bF-So.

United Nations, 20I8. "United Nations Multidimensional Integrated Stabilization Mission in the Central African Republic." http://www. un.org/en/ peacekeeping/missions/minusca/

United Nations Security Council. 20I4. "Panel of Experts on the Central African Republic." http://reliefweb.int/sites/reliefweb.int/files/resources/ Ni453897.pdf

\section{ABSTRACT}

In 20I3, following the coup led by the Séléka, a rebel group consisting of a Muslim majority, Christian militias also known as anti-Balaka decided to retaliate. This violent dispute deteriorated the already poor conditions in the Central African Republic (CAR). Although United Nations (UN) established a multidimensional peacekeeping mission in CAR, MINUSCA has not been effective to contain the conflict and prevent a humanitarian crisis. Thus, this paper examines a new concept for structuring peacekeeping forces in Africa, particularly in Central African Republic, which is the establishment of a permanent African peacekeeping force. Following a bibliographic research and an interview with a Brazilian military observer, who was deployed in CAR, it was possible to verify that the national military contingents that integrate MINUSCA face serious problems such as low level of troop training, delayed salaries, partiality, and even human rights violations of civilian population, undermining UN credibility in the country. In order to improve the effectiveness of the military force 
in CAR, a permanent African peacekeeping force, as a branch of African Union (AU) and under the control of MINUSCA, seems to be more likely to succeed, since this troop would be more impartial, better paid, and specifically trained for peace operations.

\section{KEYWORDS}

Permanent African Peacekeeping Force; African Union; United Nations; MINUSCA.

Received on September 19, 2018. Approved on January 11, 2019. 